\title{
On a correct diet: exploration of the orthorexia construct from the essential nuclei of experimental discourse
}

\author{
Sobre uma alimentação correta: exploração do constructo ortorexia desde os núcleos essenciais do \\ discurso experimental
}

\author{
En torno del apetito correcto: exploración del constructo ortorexia desde los núcleos esenciales del \\ discurso experiencial
}

Ginés Mateo-Martínez ${ }^{1}$ Maria Carmen Sellán-Soto ${ }^{1}$

1. Universidad Autónoma de Madrid.

Madrid, España.
Corresponding author:

Ginés Mateo-Martínez.

E-mail: gines_wabisabi@hotmail.com

Submitted on 12/01/2016.

Accepted on 02/13/2017.

DOI: 10.1590/2177-9465-EAN-2016-0350

\begin{abstract}
Objectives: To explore the experience lived by some women who are concerned with following a natural and organic diet. Method: The qualitative analysis of the discourse was done as a bricolage (thematic content analysis and phenomenological interpretative analysis, using different ad hoc techniques). Results: The subjective experience of women consists of a phenomenological field that defines their historicity: past, represented by the theme "Why did you choose to eat like this"; present, "An optimism recreated"; and imagined future, "Absence of disease as object of ideal consciousness". This phenomenological field evolves, in experience and discourse, as an intermittent dilation of the theme "The expansion of consciousness in the right appetite". Conclusions: The orthorexia construct and the correct appetite discourses should be explored in greater depth by the scientific community in order to investigate: social stigmatization of people concerned with healthy eating and, in an associated way, pathologization of condition.
\end{abstract}

Keywords: Orthorexia; Women; Eating Habits; Qualitative Research; Healthy Eating.

\section{Resumen}

Objetivos: Explorar la experiencia vivida por parte de mujeres preocupadas por seguir una alimentación natural y ecológica. Método: Se realizó el análisis cualitativo del discurso a modo de bricolaje (análisis de contenido temático y análisis interpretativo fenomenológico, utilizando diferentes técnicas ad hoc). Resultados: La experiencia subjetiva de las mujeres está constituida por un campo fenomenológico que define su historicidad: pasado, representado por el tema "Por qué ha decido comer asi"; presente, "Un optimismo recreado"; y futuro imaginado,"Ausencia de enfermedad como objeto de consciencia ideal". Dicho campo fenomenológico evoluciona, en experiencia y discurso, a modo de dilatación intermitente en el tema "La expansión de la consciencia en el apetito correcto". Conclusiones: El constructo ortorexia y los discursos del apetito correcto han de ser explorados más en profundidad por la comunidad científica para investigar: estigmatización social de las personas preocupadas de la alimentación sana y, de modo asociado, patologización de la condición.

Palabras clave: Ortorexia; Mujeres; Hábitos Alimenticios; Investigación Cualitativa; Alimentación Saludable.

\section{Resumo}

Objetivos: Explorar a experiência vivida por algumas mulheres preocupadas em seguir uma alimentação natural e orgânica. Método: Foi realizada a análise qualitativa do discurso a modo de bricolagem (análise de conteúdo temático e análise interpretativa fenomenológica, utilizando diferentes técnicas ad hoc). Resultados: A experiência subjetiva das mulheres consiste em um campo fenomenológico que define sua historicidade: passado, representado pelo tema "Por que escolheu comer assim"; presente, "Um otimismo recriado"; e futuro imaginado, "Ausência de doença como objeto de consciência ideal". Dito campo fenomenológico evolui, na experiência e no discurso, como uma dilatação intermitente do tema "A expansão da consciência no apetite correto". Conclusões: $\mathrm{O}$ constructo ortorexia e os discursos do apetite correto devem ser explorados em maior profundidade pela comunidade científica, a fim de investigar as ressonâncias do fenômeno em diferentes contextos: estigmatização social das pessoas preocupadas com uma alimentação saudável e, de modo associado, patologização da condição.

Palavras-chave: Ortorexia; Mulheres; Hábitos Alimentares; Pesquisa Qualitativa; Alimentação Saudável. 


\section{INTRODUCTION}

At present, observable realities that condition the human being's life at an organic, psychological, social and cultural level are established. Some of these are the overproduction of communication devices; the hyperbolic distribution of images and advertisements, ${ }^{1,2}$ which foster concern and increase interest in body image ; $^{3-5}$ the incidence, increasingly, of cancer, anxiety and stressful environments; ${ }^{6,7}$ and the interest overwhelmed by aesthetic factors such as facial and body perfectionism, muscle hypertrophy and definition, and non-healthful antiaging. ${ }^{8,9}$

These realities, insofar as they manifest a certain social and health situation relatively emergent and expansive, form a nest disturbed by the celerity of sociocultural processes, globalization and virtual worlds; ${ }^{10}$ for example, the quantitative and qualitative increase of chronic diseases, and the indiscriminate cult of the body, somehow justify some of the dietary behaviors and ideologies. ${ }^{11}$ It makes sense, therefore, to consider such provisions for food as reactive and/or coercive processes to multicultural influence, the virulent multiplication of food-related images and their commercialization, and the huge increase in seemingly unlimited virtual spaces in which "everything is possible". ${ }^{12}$

Focusing on the issue in question (human provisions for food), there are two that seem to be established as epidemiological oppositional conditions: on the one hand, frequent consumption of fast-food and, on the other extreme, avoidance of food that does not come from natural or reliable sources, and interest in functional foods (antioxidants, anticancer, depurative, etc.). ${ }^{13}$ Here, the human disposition for food and healthy food comes into play, since, among other reasons, it is a less researched subject and, in principle, it is given less risk to health.

That disproportionate interest in healthy food, viewed from the perspective of translating that inclination into the terms of concern or obsession, is defined by the American doctor Steven Bratman. The term defined by the author in the year 1997 is orthorexia; the word comes etymologically from the Greek ortos (correct) and from orexis (appetite), that is, literally, correct appetite. Bratman argues that it is a disorder characterized by an obsession with food considered healthy by the sufferer, which sometimes leads to a state of malnutrition and even death. ${ }^{14}$ In short, this definition is the first conceptualization and the theoretical embryo on which the orthorexic panorama develops as a health problem.

Although the epidemiological evidence of orthorexia is quite small, there are studies that report, with more or less success, on the magnitude of the problem. On the one hand, there are studies that indicate the prevalence in the general population, although most show calculations of orthorexic proportion in small samples and of greatly defined profiles. The prevalence in the general population is estimated to be $6.9 \%$, and in highrisk groups (health professionals and artists) between $35 \%$ and
$57.8 \% .{ }^{15}$ On the other hand, in Spain, some specialists assure that, among their consulted, the $0.5-1 \%$ presents orthorexia. ${ }^{16}$

The social impact delineates in some way the profile of the most vulnerable subjects. In the reviewed literature, there are studies focusing on environmental and contextual aspects (virtual social networks, information and communication technologies, television, shops, etc.), as well as internal aspects (values, religions, ideologies, etc.). The main characteristics of the orthorexic profile are the socio-economic level, the profession and the higher educational level and/or linked to health, and social ideals (ecology, environmentalism, salutes', etc.). ${ }^{17} \mathrm{~A}$ study shows the relationship of choice of a university career in terms of food behavior. In sporting and dietetic students, the orthorexic condition is related to body dysmorphic disorder. ${ }^{18}$ In a multivariate regression analysis in athletes, diet, age, number of concerns, and rituals were predictors. ${ }^{19}$ And as data concerning gender and age, although the orthorexic disposition occurs more in men and in different age groups, it continues to be proportionally superior in women, ${ }^{20,21}$ being, in short, a risk factor of mental and physical health. ${ }^{22}$

In a similar way, there is bibliographic testimony that supports the condition of orthorexia as a lifestyle in which fits the appearance (esthetics), and the cultivation and processing of food (nature or essence); the purchase of non-toxic food (organic, ecologic, pure, without pesticides or other artificial products) and a thorough examination of its components; 23 food and ritual practices according to a logic of care that also engages the family; ${ }^{24}$ illusory sense of security (belief in preventing disease), a need for absolute control over oneself, "a hidden conformism" to achieve a culturally accepted model as beautiful perfectionism towards oneself and oriented to others, fruit of self-demand and social constructions; ${ }^{25}$ the search for spirituality and identity, and desire for self-aspiration; and the loss of social networks and affective dissatisfaction that favors in unison the obsessive preoccupation with food, in principle to treat or improve health, and then to become the diet the center of life. ${ }^{26}$

In order to compare epidemiological results, more representative sample studies and more accurate measurement instruments are needed. ${ }^{15}$ Several studies have been carried out to date in which the reliability and validity of the ORTO-15 diagnostic orientation questionnaire are threatened. First developed by Bratman, the study has experienced modifications in its various validation attempts in other languages, as well as in its psychometric development to know psychosocial factors and comorbid psychopathology. ${ }^{27}$ Consequently, due to insufficient research (ambiguity and variability in results) and because it is a multifaceted reality, a qualitative study approach is necessary in orthorexia; in fact, there are studies that rely on the requirement of an empirical-holistic approach and an interpretative analysis. ${ }^{23}$

The increase in literature and other documents, relevant clinical experience and research studies in recent years circumscribe the relevance of the topic: ${ }^{15,17}$ the cult of the 
body and various orientations in eating behavior are evident in current Western society. Good physical appearance and health are synonymous with happiness and, therefore, people are attracted to healthy products and activities. ${ }^{16} \mathrm{All}$ this contextual drawing of the orthorexia phenomenon comprises, more or less simultaneously, several processes that converge to the same path: the culture of health and, moreover, the culture of healthism (conception of health as individual responsibility, understood as an end in itself, as a virtue that must be valid for each and every human being, instead of being considered as mean to achieve life projects)..$^{28}$

With the purpose of exploring in depth and from a sociocultural perspective the construct orthorexia, with holistic approach and from the sense that has been pronounced in this introductory text, it is proposed to carry out a qualitative study in the Comunidad Autónoma de Madrid, attending to the presence and collaboration of organizations, social movements and/or human profiles in favor of the culture of the healthy and ecological. It is proposed, as an initial general objective, to explore the experience of people with orthorexia (concern or obsession with healthy eating).

The objective initially proposed, from the dynamism and reflexivity of the qualitative research approach, has evolved to definitively establish itself as a general objective, to explore the experience lived in women concerned about a natural and ecological diet. The specific objectives are to identify concepts and ideas that describe the experience and to know strategies of constitution of the experience.

\section{METHOD}

To make an approximation to the lived experience, that is, to know the subjectivity in relation to the phenomenon of study here called (concern to follow a natural and ecological diet), the qualitative tradition in research attends to the words of the people, spoken and/or written, and observable behavior, for the production of descriptive data. As well, phenomenological orientation is essential for the conception of qualitative methodology, insofar as the researcher's disposition is, ultimately, to see things from the point of view of other people, inquiring into the subjective world of human experience for their comprehension. ${ }^{29,30}$

Symbolic Interactionism would rest on three main premises: people act on things and on other people, based on the meanings that such things have for them, being the meanings, definitely, those that are determining human actions for others and for themselves; meanings are social products fruit of interaction; and social actors attribute meanings to situations, people, things and themselves through a process of interpretation. ${ }^{29}$

From the initial methodological proposal generated by the philosopher Husserl, that is, without abandoning the phenomenological precept of "to the proper things", of the approach to the essences, of the description of the essences manifested in the consciousness, the Phenomenological
Reduction is proposed as a process of categorization, of the essentialization of the experience and, finally, of access to the experience of the participating subjects. . $^{31,32}$ Also, maintaining the premise of Phenomenological Reduction in the field of sociological analysis, it is necessary to dispense with the conception of Transcendental reduction (as a process of absolute disconnection from the reality of the world) and to consider the use of eidetic reduction as a psychological method capable of interpretation, that is, as a process of objectification of consciousness through eidetic variation, ${ }^{33,34}$ in which it also interferes or interacts, to finally be described the phenomenon as a structure possible to conceptualize and comprehend, the hermeneutic disposition of the researcher as a subject of interpretation of what, already interpreted by the participants in the process of eidetic variation of objectifications in the consciousness for access to the constitutive essences of the experience, manifests itself through language and the intersubjective process of reciprocal communication between the symbolic worlds of the researcher and of the subjects participating in the study. ${ }^{29}$

This research work has been carried out in the Comunidad Autónoma de Madrid. M. F. CÁTERING ECOLÓGICO, S.L. has been the social domicile where the researcher was allowed to introduce himself, to become gradually involved and to participate in the phenomenon of study.

In the first instance, the inclusion criteria that have been established for the study population have been as follows: $a$. Men or women diagnosed with orthorexia. b. Men or women with an obsession for healthy eating.

These inclusion criteria have been remodeled, to finally be established as: a. Women worried about a natural and ecological diet. B. Women who, without having to be diagnosed, maintain a lifestyle around healthy food.

As sampling strategies in the course of the research work, the first step has been to access the field of study by means of purpose-based sampling (selection of informants in terms of accessibility, that is, easy access and location). ${ }^{35}$ Limitations of access to comparable fields of study (other spaces and organizations for natural and ecological food) have led to the methodological decision to snowball sampling (access to new informants opportunistically through other contacts). ${ }^{36}$

Based on analytical inferences and the emergence of hypotheses, the data collection has been redirected in a more focused way (theoretical sampling), allowing a more congruent and structured understanding of the phenomenon. ${ }^{35}$ Moreover, in later phases of the analysis, the sampling by extreme cases, with the in-depth analysis of informants with powerful and explicit discourses, have helped in the understanding of the phenomenon also from a theoretical proposal. ${ }^{37}$

In the present study, three participant observation sessions of six to seven hours each have been used; And four in-depth interviews have been conducted with women concerned about a natural and ecological diet. 


\section{Characteristics of the sample}

\begin{tabular}{lcccc}
\hline INFORMANT & AGE & ACADEMIC LEVEL & LABOR PERFORMANCE & $\begin{array}{c}\text { CONDITIONING DISEASE OF } \\
\text { FOOD }\end{array}$ \\
$\begin{array}{l}\text { ML (most relevant social actor } \\
\text { in participant observation) }\end{array}$ & $50 / 55$ & University studies & $\begin{array}{c}\text { Administration and } \\
\text { Nutrition }\end{array}$ & Cancer (in the past) \\
\hline E & 42 & Primary studies & Monitors sports center & $\begin{array}{c}\text { Son with chronic metabolic } \\
\text { disease }\end{array}$ \\
\hline M (elite informant) & 42 & University studies & Agricultural engineering & Cancer (in the past) \\
MA & $40 / 45$ & University studies & Medicine & Not referred \\
\hline
\end{tabular}

\section{Data collection techniques}

In the process of collecting data for the generation of research work, different techniques have been used according to field needs and the demands of the analytical process, opting for the triangulation of observational technique and conversational techniques. As an observational technique, participant observation has enabled the first entry into the field of information of the phenomenon, giving access and allowing the progressive knowledge of the operation of women concerned about a natural and ecological diet, by identifying their modes of interaction, activities, values and beliefs, common discourses, among others. Conversational techniques (open interviews and in-depth interviews) have facilitated access to the lived experience, through a process of deepening the search for knowledge about the phenomenon. ${ }^{29,31}$

\section{Data analysis}

In the qualitative research tradition, working with data is a process in continuous progress, so that the collection and analysis of the same is carried out simultaneously or at least within a dynamic of feedback and flexibility Collection techniques, analytical approaches, and even research objectives. ${ }^{29,38}$

This article details the phases of reduction and organization, ${ }^{39}$ as well as the domains of discovery and codification; ${ }^{29,38}$ the rest is constituted, by its extension, in an independent but complementary paper of the study.

\section{Strategy 1: Discovery}

In the discovery strategy the following memorandum has been made, which has proved especially useful for identifying emerging issues, as well as their hypothetical trend in the evolution of data analysis. The memorandum has consisted of a classification closely related to the informants' discourse, according to their words, phrases and modes of expression, for the elaboration of a noetic-noematic syntax table or correlation of noesis (forms) and noemas (contents); Establishing thematic labels for the first impressions of meaning and descriptive meanings of the phenomenon. Thus, from the initial proposal as bricolage, a series of ad hoc analytical techniques have been used, in the first instance to facilitate to the investigator "what is there" and "what goes with what" in the data: (I) warning patterns and themes; (II) counting; and (III) grouping the content according to the discursive weight and modes of representation (looking for underlying guidelines for the first hypothetical associations), understanding noemas as natural discourse (natural linguistic units), and noesis (syntactic structurants) as the weight of the speech and the order of appearance based on spontaneous self-reflection (repetition or return of the same subject) and fruit of the interaction between informant and researcher. ${ }^{38}$

\section{Strategy 2: Codification}

With the coding strategy, the vague ideas and intuitions of the beginning of the research process are being polished, expanded, discarded or further developed in depth. The suggested steps for the development of this strategy, according to Taylor and Bogdan, are: ${ }^{29}$ development of coding categories, making a list with all the themes, concepts, interpretations, typologies and propositions, identified or produced in the initial phase of discovery analysis; Coding all the data, assuming the negative and positive incidents linked to each category and, in unison, refining the coding scheme by adding, expanding, deleting and redefining the categories, making the codes plausibly fit the data; separate the data belonging to each coding category; discard the remaining data after a thorough review of the data not entered in the analysis; refine the analysis taking into account the probability that some ideas and concepts will not fit the data, and that some propositions lose validity, having to eliminate them and develop others more appropriate.

\section{RESULTS}

The results are presented in a logical sequence, taking into account the two strategies of analysis used: result of the discovery of the data, a noetic-noematic correlation table was obtained (table 1); and as a result of codification, a memorandum has been developed that evolves in a sense of inquiry, deeper understanding and abstraction of the correct appetite phenomenon (table 2: essential feedback cores supported with narrative memos, for the development of dynamic codes and meanings). 
In each of the representations, the most relevant are recorded, with a process of reduction and additional selective disposal so that the results can be communicated, for extension purposes, without affecting the congruence and the amplitude of the phenomenon.

\section{DISCUSSION}

The results represented in the present study with respect to the correct appetite are in tune with some studies in which the characteristics of people with orthorexia or with a pathological inclination are indicated for the food considered healthy; ${ }^{23,27}$ that is, their ideology (what and how they think) is in line with the themes expressed in this paper "The World of Healthy Eating", "Why I Choose to Eat It" and "Absence of Infirmity as an Object of Ideal Consciousness". The set of strategies and constitutive mechanisms of experience (what do they do), are related with the theme "A recreated optimism", as an exercise of feedback of the condition between knowledge, manipulation and consumption of natural and organic food.

With respect to the results represented by the expansion of the healthy condition in the right appetite, there is a study in which the orthorexic profile is defined as a person of high socioeconomic level and higher academic level, informed and researcher of everything in terms of food and natural and ecological food. ${ }^{15}$ This aspect tunes in with the topic "Investigating and informing", "My purchase" and "Qualifying the reliability of food".

On the other hand, there are no qualitative studies of discourse analysis, or of approximation or understanding of the experience lived by people worried about healthy eating; so that the present work contributes, as a novelty, to the subjective experience of these people.

Table 1. Noetic-noematic correlation (natural linguistic units, discursive weight and order of appearance).

\begin{tabular}{|c|c|c|}
\hline NOEMAS & NOESIS (discursive weight) & $\begin{array}{l}\text { NOESIS (order } \\
\text { of appearance) }\end{array}$ \\
\hline $\begin{array}{l}\text { 'One thing has led to the other' } \\
\text { 'From very small' } \\
\text { 'My mother instilled it to me' } \\
\text { 'A health problem of a child' } \\
\text { 'I got into healthy eating' }\end{array}$ & $\begin{array}{c}\text { Process origin } 3,3 \rightarrow 6 \\
\text { Justification for condition } 2,1,2,3 \rightarrow 8\end{array}$ & $\begin{array}{l}10 \\
20\end{array}$ \\
\hline $\begin{array}{l}\text { 'Constant' } \\
\text { 'Constancy' } \\
\text { 'Advantages' } \\
\text { 'Delaying possible diseases' } \\
\text { ‘Delay aging' } \\
\text { 'Feel better' }\end{array}$ & $\begin{array}{c}\text { Characteristics of the proper condition 2, 2, 1, 1, } 1 \rightarrow 7 \\
\text { Purposes of condition } 3,1,1,3,3,8,2 \rightarrow 21 \\
\text { Positive feelings and sensations } 1,1,1,5,5 \rightarrow 13\end{array}$ & $\begin{array}{l}3 ㅇ \\
4 ㅇ \\
5 ㅇ\end{array}$ \\
\hline $\begin{array}{l}\text { 'In the physical, in the skin' } \\
\text { 'No major illness' }\end{array}$ & What do you see as benefit $2,2 \rightarrow 4$ & 9o \\
\hline $\begin{array}{l}\text { 'World of food' } \\
\text { 'Something that sells' } \\
\text { 'They are taking advantage of the hype' } \\
\text { 'The media' } \\
\text { 'More people who care about healthy living' }\end{array}$ & $\begin{array}{l}\text { The world of food } 1 \\
\text { Commercialization by the media } 3,1,1 \rightarrow 5 \\
\text { Expansion of the condition in number of people } 1,1 \rightarrow 2\end{array}$ & $\begin{array}{l}150 \\
160 \\
170\end{array}$ \\
\hline $\begin{array}{l}\text { 'Things I hear' } \\
\text { 'I do not entirely agree' } \\
\text { 'Want to sell something that is a lie, which is false' } \\
\text { 'Cheating the consumer' }\end{array}$ & $\begin{array}{l}\text { Disagreement with the media } 3,3 \rightarrow 6 \\
\text { Feeling of deception } 1,1,1,1,1 \rightarrow 5\end{array}$ & $\begin{array}{l}180 \\
190\end{array}$ \\
\hline $\begin{array}{l}\text { 'Healthy eating makes me feel great' } \\
\text { 'I know I'm a healthy person' } \\
\text { 'Exceptions' } \\
\text { 'Should not have done' }\end{array}$ & $\begin{array}{c}\text { Consciousness of one's own healthy condition } 1,1 \rightarrow 2 \\
\text { Regret or guilty conscience } 1,1 \rightarrow 2\end{array}$ & $\begin{array}{l}20 \circ \\
210\end{array}$ \\
\hline $\begin{array}{l}\text { 'Am I in the world of such people?' } \\
\text { 'Something that I may identify myself with' }\end{array}$ & Identification with the diagnostic proposal 2 & 640 \\
\hline $\begin{array}{l}\text { 'Obsession no' } \\
\text { 'It is concern' }\end{array}$ & Self-concept confrontation/diagnostic definition 2 & 650 \\
\hline
\end{tabular}


Table 2. Essential nuclei of feedback/narrative memos. The geometric representations constitute the essential nuclei, fed by the themes "vertices", expanding according to their discursive weight in the process of manifestation of the discourse.

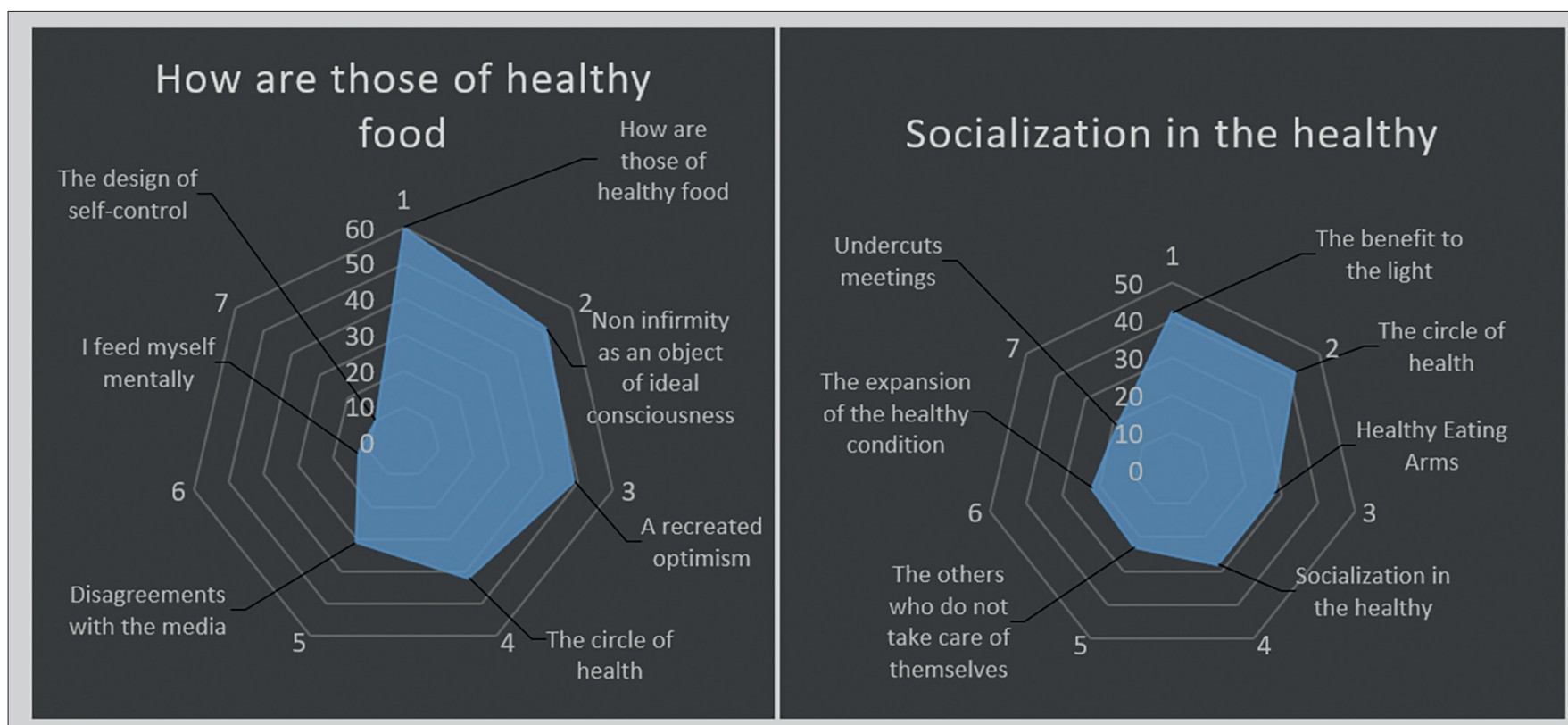

The theme of Non-infirmity as an object of ideal consciousness seems to refer, more or less consistently, to a thought and an ideation in which the disease is constructed as something to be eliminated (also, due to the reiteration and emphasis of the informants in this idea, seems to be established primarily as basis of the condition of concern for healthy eating), through a strict and complexly designed self-control: design of self-control; of which one is absolutely conscious, blurring in the speeches a certain alliance/symbiosis between food and the mind (I feed myself mentally).

On a more collective level, women who are concerned about healthy eating seem to strengthen the condition in the community where the experience of healthy is bet and lived in the first person (The circle of health).

These women also seem to be defined as opposites to the products and ideas sold by the media (Disagreements with the media), generating, in unison, A recreated optimism, reconstructed by manifesting itself through feedback of positive thoughts and dispositions, whether born from inside, or arising from the external world, although seemingly contrary to the environment.

The modes of socialization in the contexts of the healthy, in the informant women, seem to obey two more or less contradictory aspects: on the one hand, a rich discourse appears around the field of the experience of the healthy, in which the experience seems to have a strong sense and desire to be expressed, informed and expanded (The circle of health); this theme is positively nourished by the theme Benefit to the light, which refers to aspects (physical and psychological, and even spiritual), which are favored by the provision of healthy food.

A result of this apparent phenotypic and mental benefit, the disposition of the informants is of communication, of information to others, of infecting their own condition, although not in the way that the media do (The expansion of the healthy condition).

However, the other side seems to be based around the meetings of women with other people (relatives, friends, etc.) who do not share the natural feeding arrangement, resulting in Undercut meetings and creating a certain contempt for the rest which is not like them (The others who do not take care of themselves). 
Continued Table 2.

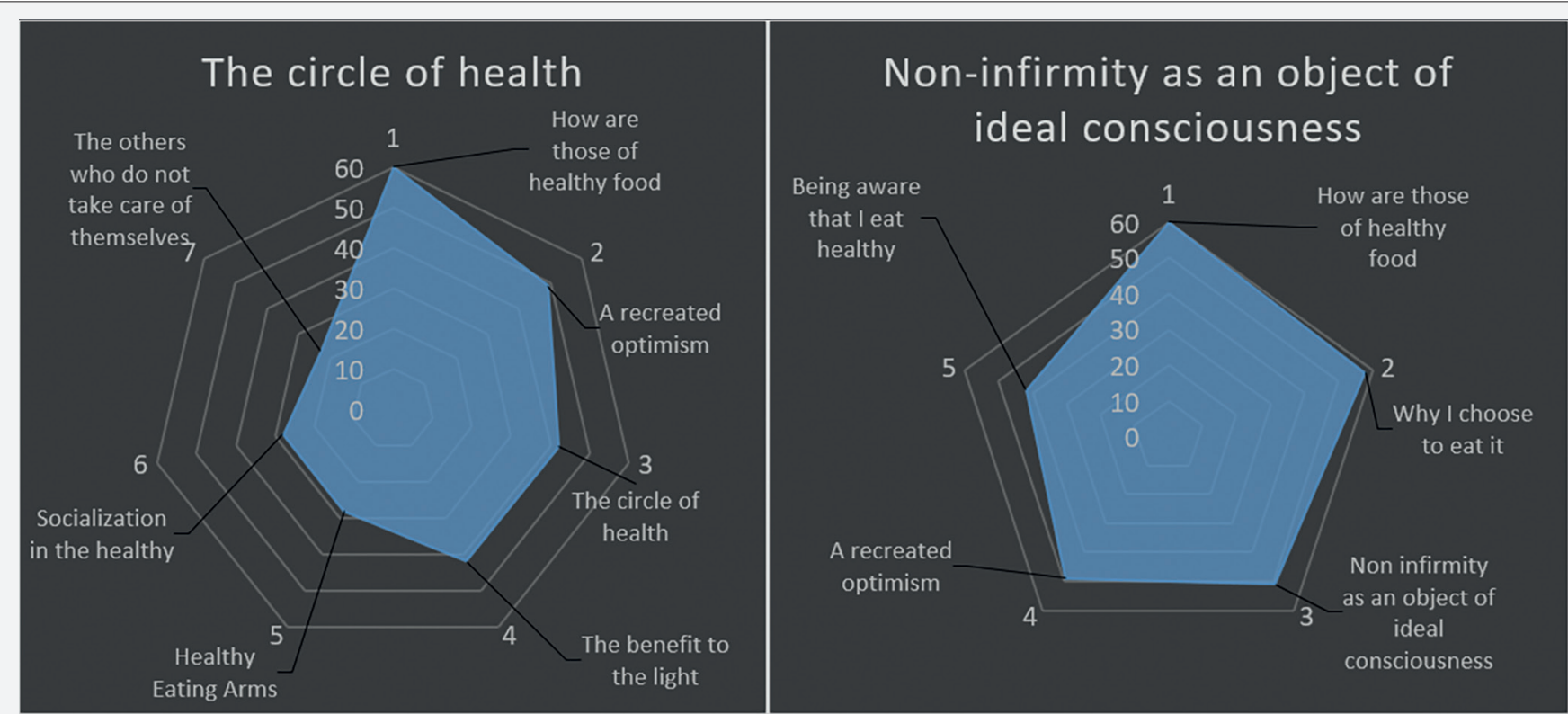

This essential theme is covered by other themes to lead and redirect the definition of the condition of concern for natural and ecological food (How are those of healthy food).

Within the Circle of healthy, the theme of A optimism recreated, by The benefit to the light and Eating Healthy Arms seems to be potentiated as a compendium of extensions generated from the own disposition towards other spheres and contexts, as conqueror of other territories, as an exit from the subjective to the external and to the objective; in spite of obstacles and people who do not support or do not identify with the phenomenon (The others who do not take care of themselves). Around the non-infirmity seems to blur the sense (also the basis and purpose) of the condition of these women (why the latter?). By means of a recreated optimism, fully self-produced and conscious (conscious that I eat healthy), women seem to be described, as well as justified repeatedly (How are those of healthy food), to then allow to see - and be seen - as a reward (self-validation, self-recognition of its good/proper performance), the result of non-infirmity, as an intermittent or latter reality (Why I choose to eat like this). 


\section{Continued Table 2.}

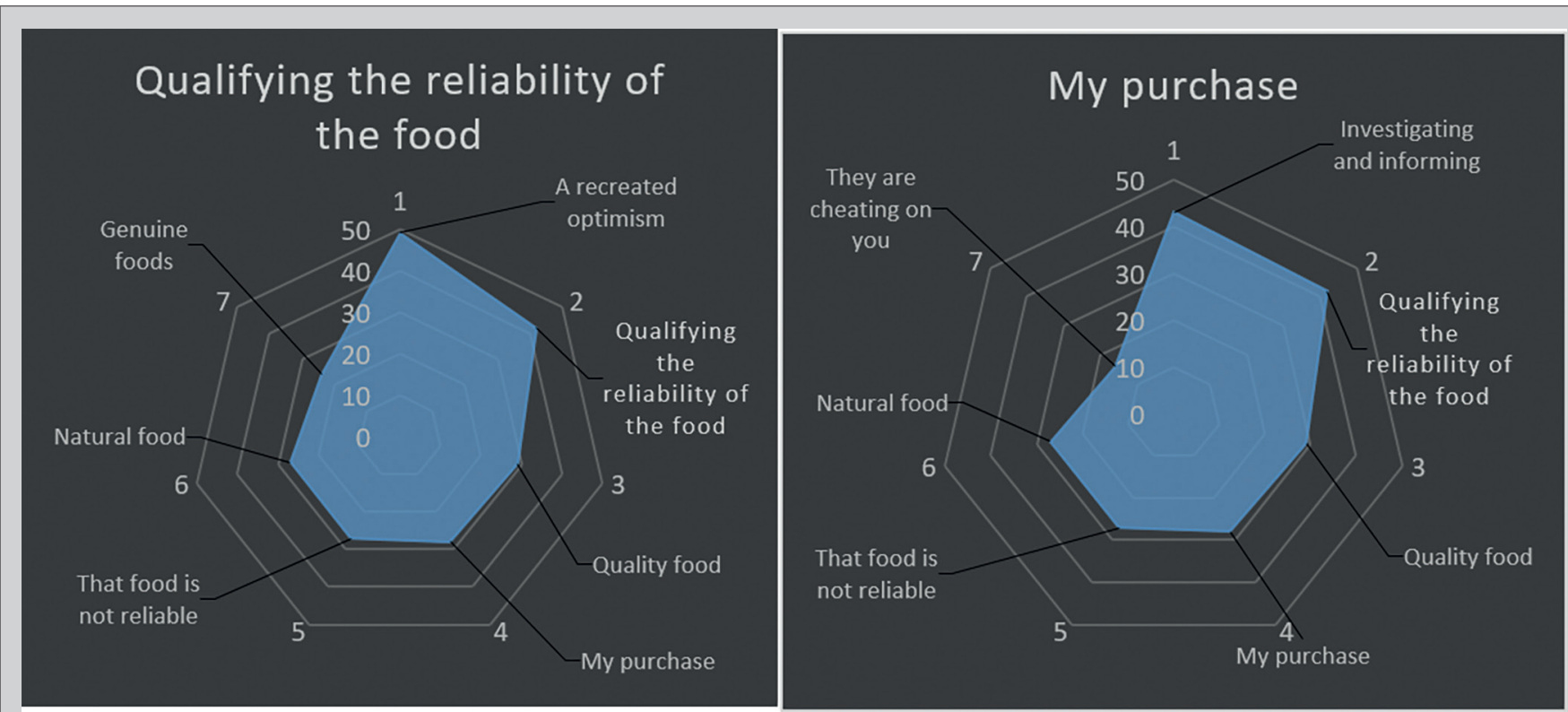

This essential theme is constituted around a body of knowledge (ideas and concepts) about the quality, the presentation, the genesis and the processing of the foods, seeming to adjudicate to each type of food a surname or distinctive qualifier, representing different functions and applications (Quality Foods, Genuine Foods and Natural Foods). The genuine food seems to be the one cultivated by oneself, knowing its entire process, to be directly consumed. The natural is the food raised in clean contexts, without manipulations or prosecutions; and quality food is nevertheless seen as a food that, despite being part of a merchandising network, complies with the quality certification protocols required by the ecological community.

The reliability rating seems to occur, in particular, at the time of purchase (My purchase), a circumstance in which the decisions regarding the reliability of the products offered seem to be taken (That food is not reliable), new generating An optimism recreated in that the decision making is according to some precepts and ideals of naturalness and ecologism.

The purchase is apparently defined as a moment, rather than as a recurring fact. That is to say, each purchase made is lived as a time in which the exhaustive checking of the quality of the food (Qualifying the reliability of the food) is merged, while censorship decisions are made (That food is not reliable), and one lives in unison a sense of deceit projected on those who sell (supermarkets, shops, advertisements); even seems to live a feeling of deception or betrayal by the food properly, as long as it is not shown as the expected way (They are cheating on you). In this sense, we choose, as far as possible, Quality Foods and Natural Foods.

These purchasing and decision-making moments in terms of food reliability and quality seem to be conditioned and fed by a transverse search and information gathering and even thorough investigation of ingredients, food combinations, cooking methods, ecological companies, among others (Investigating and informing). 


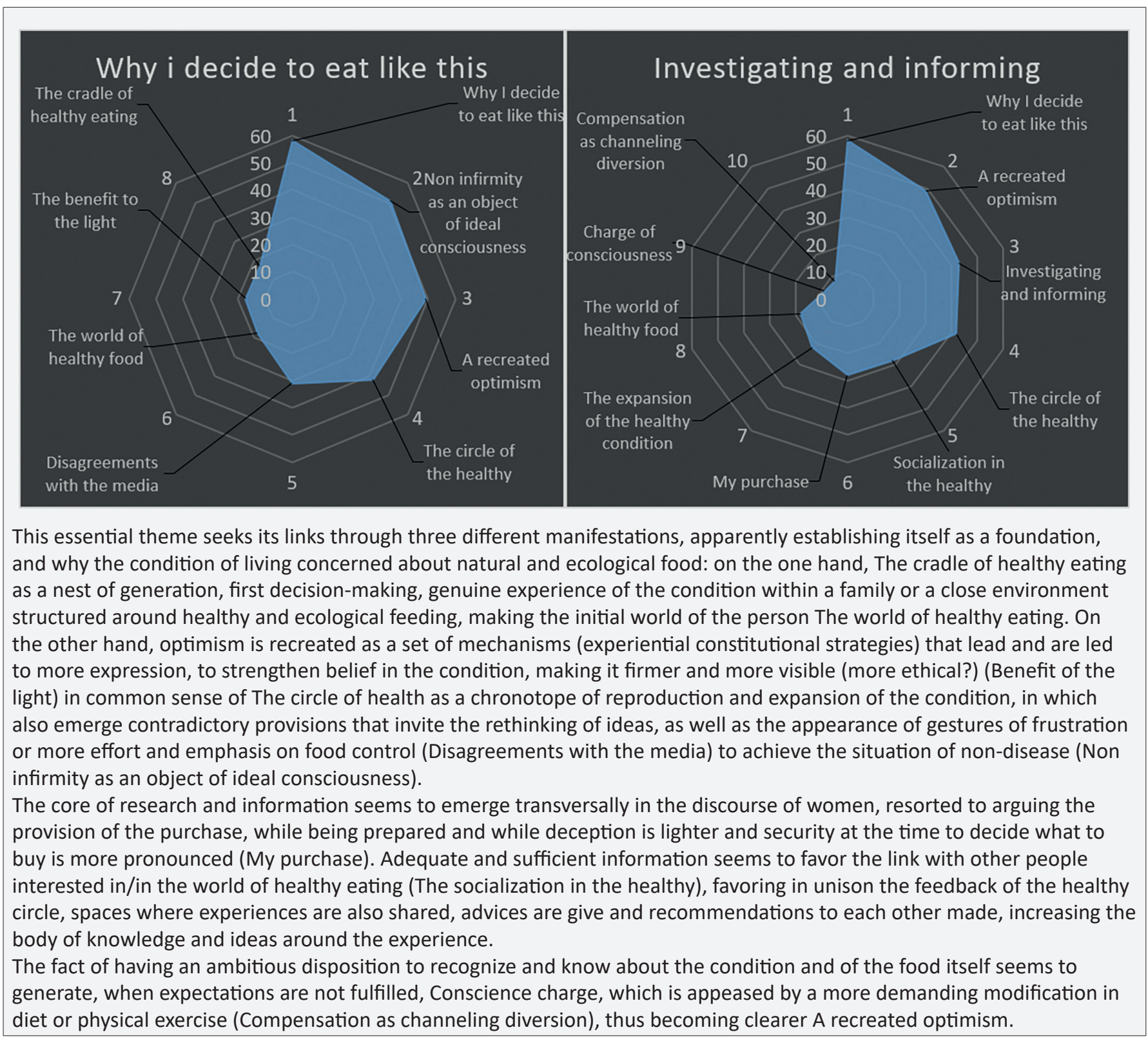




\section{Continued Table 2.}

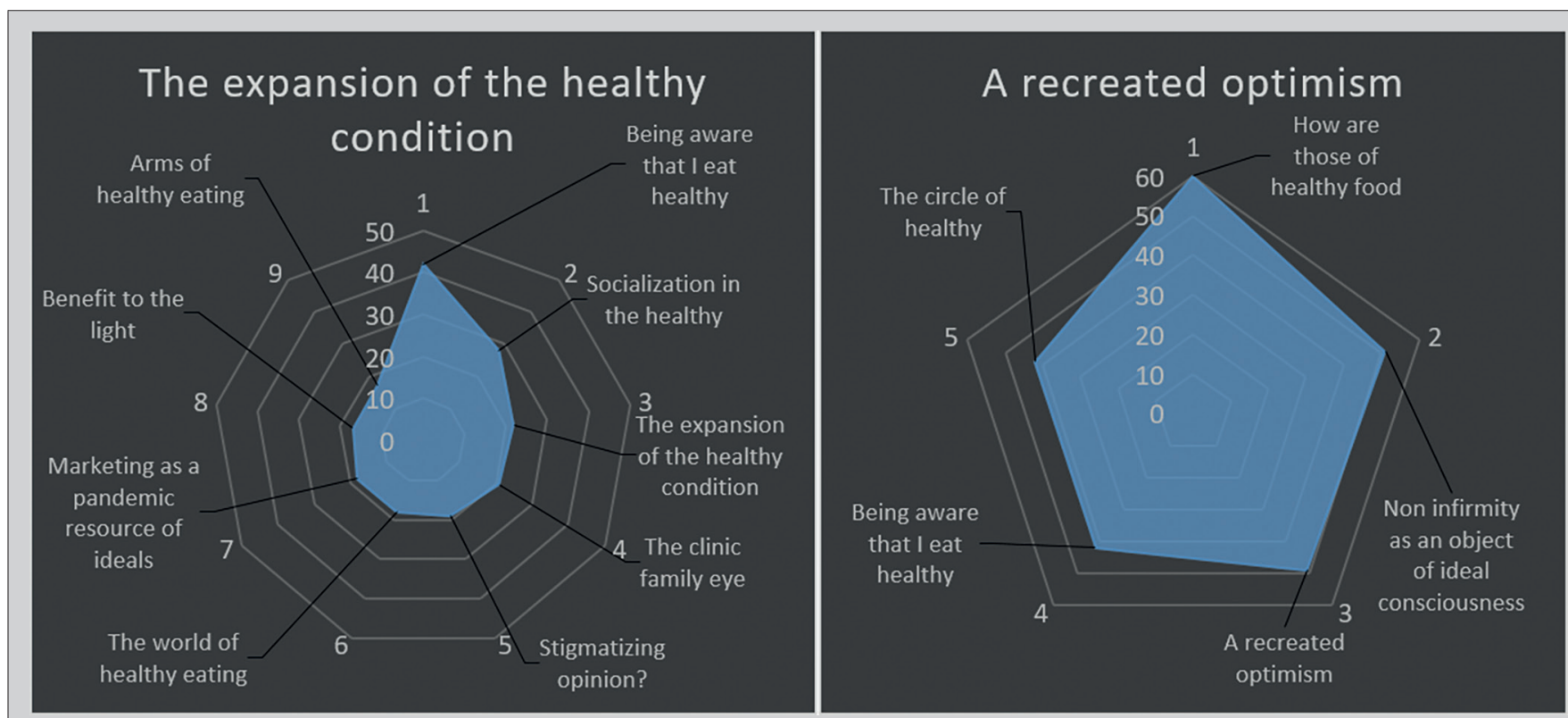

At the time that is available the search for information and investigation on the part of these women, emerges a subject which, although it is not feedbacked the most, manifests itself in a diverse way, that is, in many subjects. Having an awareness of a well-rooted healthy condition (Being aware that I eat healthy) seems to lead to a gradual and irregular dilation of the condition in the immediate environment, making the woman in question a focus of attention and protagonism (The family clinic eye); as well as more or less offensive considerations and opinions within the socialization itself (Socialization in health, stigmatizing opinion?); and other more constructive comments, although it is not clear whether with a certain disposition of envy of the others towards the women (The benefit to the light).

The world of healthy food seems to evolve, as an expression and manifestation of the experience of women, as an expansion: embracing the environment; wanting to compromise and convince morally and politically the environment (Arms of healthy eating), placing it as a victim of conventional mercantilization of health (Marketing as a pandemic resource of ideals).

Optimism (expressed through strategies and gestures of self-control, food correction, firm beliefs in the condition, etc.), is shown above all associated with a remarkable mental disposition in which one is conscious and one assumes the condition despite of the limits and criticisms of the environment (family or society) (Being aware that I eat healthy). This feeling of optimism (which can also be termed as a non-surrender, a reaffirmation (an obsession?), emerges more stable in the circle of health, allowing also, more expansively and reciprocally to describe similar people or of the same condition (How are those of healthy food), in order to aspire (delaying, avoiding, evading, not wanting the real situation of illness - in the present or in the past, of some close person or even of the world in general), to an idealized situation more or less lax in time, although projected in a rather distant future, of non-disease (non infirmity as an object of ideal consciousness).

The limitation that arises when comparing studies on the same phenomenon (orthorexia) must be assumed, based on the fact that the studies published until the present are of a quantitative nature and not elaborated from a constructivist paradigm. Thus, on the one hand, there is a gradual and, in the last years, more drastic growth of epidemiological studies that expose the prevalence of the orthorexic condition through the application of the Bratman test, with a diagnostic orientation; ${ }^{18,40-42}$ while analyzing subjective experience, there is a clear instability, which generates ambiguity, which invites us to think of the inadequacy of the construct, as a term and as a meaning whose attributes are "social stigmatization" and "obsession as a defining characteristic of the condition". In this sense, from the present study, consideration of the correct appetite as pathology leaves breach for questioning.

On the other hand, orthorexia, either as a preoccupation or as an extreme obsession with healthy eating, is bordering on obsessive-compulsive disorder, anorexia and selective food disorders. ${ }^{24,43,44}$ The present study can help to clear those limits and know more deeply the condition of living concerned about healthy eating.

Another issue that seems to be determining in the emergence of the right appetite lifestyle is the situation of economic crisis and the new patterns of consumption of organic food in Spain. ${ }^{45}$ 
The consumption of organic food evolves increasingly, tending to normalization in certain social groups involved in ecological movements and ideologies. This data can intervene in the standardization of the condition of concern for an ecological diet; despite the struggle in its expansion, for being minority groups but increasingly visible and distributed. This argument tunes in with the theme manifested in this work "The expansion of the healthy condition".

As for the limitations of the present study, comparisons cannot be made with similar studies, since they are not available. As far as access to the field of work is concerned, the establishment of confidence and necessary rapport has taken a long time, having to bypass data sources, Having to bypass sources of data that, being through the field, have not been accessible again; and also assuming laborious analytical work simultaneously to the collection of the data. This has meant that the sampling done was more by purpose than theoretical.

Finally, some of the themes represented in the results ("Being aware that I eat healthy", "Arms of healthy eating/Marketing as a pandemic resource of ideals" and "Absence of disease as an object of ideal consciousness") although described, still invite to be perfected and more deeply understood, offering a field of inquiry in the experience of women informants: to penetrate in the sense of "conventional" ideals, in the "conscious" disposition of the condition and in "non-infirmity" as complex conceptions attributable to correct appetite. The theoretical point that should be studied with more depth in the future would be the expansion of the healthy condition, located in the midst of the turbulence of conventional society, a victim of health as a commercialized product and as a violated right.

\section{CONCLUSIONS}

The experience of women who are preoccupied with a natural and ecological diet is constituted by a thematic experiential field or subjective/interior experience that traverses their historicity (past, present and future imagined): "Why I choose to eat like this", "Optimism Recreated" and "No illness as an object of ideal consciousness", respectively. "The expansion of the healthy condition" is the exercise that identifies and progresses irregularly, dilating and retracting the condition of the right appetite in the environment, through "Arms of healthy eating/Marketing as a pandemic resource of ideals", "Benefit in the light" and "The family clinic eye: stigmatizing opinion?".

Consideration of orthorexia as a pathology is associated, apart from established biomedical criteria, with social stigmatization and difficulties of socialization, because it possesses ideologies and idiosyncratic ways of living alimentation. As a term, orthorexia is relatively offensive in producing resonances of other food conditions such as anorexia or vigorexia.
The constitutive strategies of the experience are concentrated in "a recreated optimism", in an introspective exercise and self-reflection ("How are those of the healthy food") and also within "The circle of health", with the provision/predisposition of "Being aware that I eat healthy". The global and holistic perspective of understanding, from nursing to the phenomenon of right appetite, allows for a deeper approximation, and to contemplate the meanings attributed by women to the subjective experience of their condition. Thus, the qualitative evidence makes possible an approximation to the affectivity and to the psychosocial processes, to the culture of care in the right appetite, from the deep and extensive analysis of their experiential discourses.

\section{REFERENCES}

1. Cuevas J. La imagen como mercancía: promoción y negación de la imagen técnica. [Internet]. 2nd ed. Actas IV CILCS; 2014 [cited 2016 Apr 13]. Available from: http://www.revistalatinacs.org/14SLCS/2014_ actas/056_Cuevas.pdf

2. González Ibáñez E. Ruido visual: la saturación de imágenes en la contemporaneidad. AusArt Journal for Research in Art [Internet]. 2015 [cited 2016 Feb 14]; 3(2):230-231. Available from: http://www.ehu.eus/ ojs/index.php/ausart/article/view/15964/14190

3. Martínez Fernández VA, Juanatey Boga O y Costa Sánchez C. Agenda Setting y crisis económica: influencia de la prensa en el comportamiento de consumo y ahorro. Estudios sobre el Mensaje Periodístico [Internet]. 2012 [cited 2016 Jun 23]; 18(1): 147-149. Available from: http://revistas. ucm.es/index.php/ESMP/article/view/39362/37908

4. Vaquero-Cristóbal R, Alacid F, Muyor JM y López-Miñarro PA. Imagen corporal; revisión bibliográfica. Nutrición Hospitalaria [Internet]. 2013 [cited 2016 Jan 23]; 28(1): 27-35. Available from: http://scielo.isciii.es/ $\mathrm{pdf} / \mathrm{nh} / \mathrm{v} 28 \mathrm{n} 1 / 04$ revision04.pdf

5. Ortíz Sánchez LM. Cuerpos e identidades on line: construcción de identidades corporales en el chat. Colombian Applied Linguistics Journal [Internet]. 2013 [cited 2016 Jan 23]; 15(2): 302-309. Available from: http://revistas.udistrital.edu.co/ojs/index.php/calj/article/ view/5136/6746

6. Cortes JMM, Sanz NA, Godoy P, Moros MJS, Portero RC, Moran FG, et al. Las enfermedades crónicas como prioridad de la vigilancia de la salud pública en España. Gaceta Sanitaria [Internet]. 2016 [cited 2016 Jul 22]; 30(2): 154-157. Available from: http://www.sciencedirect.com/ science/article/pii/S021391111500254X

7. Sánchez Martínez S, Rico Cano A y Ferrer Moreno CM. El estilo de vida nos define: dieta y cáncer. Salud y Cuidados en el Envejecimiento: Alimentación y Envejecimiento [Internet]. 2015 [cited 2016 Feb 28]; 3: 25-32. Available from: http://formacionasunivep.com/documents/ publicaciones/salud-y-cuidadores-en-el-envejecimiento-volumenIII. pdf\#page $=26$

8. Martínez Guirao JE. Construyendo los cuerpos "perfectos". Implicaciones culturales del culto al cuerpo y la alimentación en la vigorexia. Universitas [Internet]. 2014 [cited 2016 Jan 23]; 21: 77-99.

9. Romero Croce J. El malestar actual de la cultura y la martirización del cuerpo. Psicología y Salud [Internet]. 2012 [cited 2016 Apr 15]; 22(2): 205-214. Available from: http://www.uv.mx/psicysalud/ psicysalud-22-2/22-2/Jes\%FAs\%20Romero\%20Croce.pdf

10. Martín M y Torres M. Imágenes e imaginarios en el espacio público virtual: apuntes para una agenda de investigación. Razón y Palabra [Internet]. 2013 [cited 2016 Mar 16]; 18(82). Available from: http://www. redalyc.org/pdf/1995/199525737006.pdf 
11. De Vogli R, Kouvonen A y Gimeno D. La influencia de la desregulación del mercado en el consumo de comida rápida y el índice de masa corporal: un análisis de series temporales entre países. Boletín de la Organización Mundial de la Salud [Internet]. 2014 [cited 2015 Cec 30]; 92(2): 77-152. Available from: http://www.who.int/bulletin/ volumes/92/2/13-120287-ab/es/

12. Peñafiel $C$, Camacho I y Pastor J. Estudio de las Webs de información de salud en español y euskera dirigidas a jóvenes y adolescentes. Actas V Congreso Internacional Latina de Comunicación Social [Internet]. 2013 [cited 2016 Jan 12]. Available from: http://www.revistalatinacs. org/13SLCS/2013_actas/082_Penafiel.pdf

13. CFK. Caracterización de la tipología y perfil sociodemográfico del consumidor de alimentos ecológicos en España. Ministerio de Agricultura, Alimentación y Medio Ambiente. Perfil del Consumidor de Alimentos Ecológicos en España [Internet]. 2014. Available from http:// www.magrama.gob.es/es/alimentacion/temas/laagriculturaecologica/ estudioperfilconsumidorecologic02014_tcm7-346684.pdf

14. Bratman S y Knight D. Health Food Junkies. Ortorexia nervosa: overcoming the obsession with healthful eating. Estados Unidos: Broadway Books; 2000. p. 25-38.

15. Varga M, Dukay-Szabó S, Túry Fy van Furth EF. Evidence and gaps in the literature on orthorexia nervosa. Eat Weight Disord [Internet]. 2013 [cited 2016 Apr 14]; 18(2): 103-11. Available from: https://www.ncbi. nlm.nih.gov/pubmed/23760837

16. Cabanach Mané $C$ y López Medina MD. Ortorexia: de sana inquietud a patología. Metas de Enfermería [Internet]. 2009 [cited 2016 Feb 14]; 12(6): 14-19. Available from: https://dialnet.unirioja.es/servlet/ articulo?codigo $=3007849$

17. Varga M, Dukay-Szabo S y Túry F. Orthorexia nervosa and it's background factors. Ideggyogy Sz [Internet]. 2013 [cited 2016 Marc 21]; 66(7-8): 220-227. Available from: https://www.ncbi.nlm.nih.gov/ pubmed/23971352

18. Bo S, Zoccali R, Ponzo V, Soldati L, De Carli L, Benso A, et al. University courses, eating problems and muscle dysmorphia: are there any associations? J Transl Med [Internet]. 2014 [cited 2016 Apr 13]; 12: 221. Available from: https://www.ncbi.nlm.nih.gov/pmc/articles/ PMC4256707/

19. Segura-García C, Papaianni MC, Caglioti F, Procopio L, Nisticò CG Bombardiere L, et al. Orthorexia nervosa: a frequent eating disordered behavior in athletes. Eat Weight Disord [Internet]. 2012 [cited 2016 Apr 18]; 17(4): 226-33. Available from: https://www.ncbi.nlm.nih.gov/ pubmed/22361450

20. Hepworth K. Eating disorders today-not just a girl thing. J Christ Nurs [Internet]. 2010 [cited 2016 Feb 15]; 27(3): 236-241. Available from: https://www.ncbi.nlm.nih.gov/pubmed/20632480

21. Arusoğlu G, Kabakçi E, Köksal G y Merdol TK. Orthorexia nervosa and adaptation of ORTO-11 into Turkish. Turk Psikiyatri Derg [Internet]. 2008 [cited 2016 Jan 24]; 19(3): 283-291. Available from: https://www.ncbi. $\mathrm{nlm}$.nih.gov/pubmed/?term=Orthorexia+nervosa+and+adaptation+of +ORTO-11+into+Turkish

22. Ramacciotti CE, Perrone P, Coli E, Burgalassi A, Conversano C, Massimetti G, et al. Orthorexia nervosa in the general population: a preliminary screening using a selfadministered questionnaire (ORTO15). Eat Weight Disord [Internet]. 2011 [cited 2016 Mar 25]; 16(2): 127130. Available from: https://www.ncbi.nlm.nih.gov/pubmed/21989097

23. Håman L, Barker-Ruchti N, Patriksson G y Lindgren EC. Orthorexia nervosa: An integrative literature review of a lifestyle syndrome. Int $J$ Qual Stud Health Well-being [Internet]. 2015 [cited 2016 Jun 16]; 10 (2): 67-99. Available from: https://www.ncbi.nlm.nih.gov/pmc/articles/ PMC4539385/

24. Musolino C, Warin M, Wade T y Gilchrist P. Healthy anorexia: The complexity of care in disordered eating. Soc Sci Med [Internet]. 2015 [cited 27 Jan 2016]; 139: 18-25. Available from: https://www.ncbi.nlm. nih.gov/pubmed/26150064

25. Barnes MA y Caltabiano ML. The interrelationship between orthorexia nervosa, perfectionism, body image and attachment style. Eat Weight Disord [Internet]. 2016 [cited 2016 Jun 28]; 11. Available from:
https://www.ncbi.nlm.nih.gov/pubmed/?term=The+interrelationship+ between+orthorexia+nervosa

26. Janas-Kozik M, Zejda J, Stochel M, Brozek G, Janas A y Jelonek I. Orthorexia: a new diagnosis? Psychiatr Pol [Internet]. 2012 [cited 2016 May 22]; 46(3): 441-450. Available from: https://www.ncbi.nlm.nih.gov/ pubmed/23045897

27. Koven NS y Abry AW. The clinical basis of orthorexia nervosa: emerging perspectives. Neuropsychiatr Dis Treat [Internet]. 2015 [cited 2016 Jan 30]; 11: 385-394. Available from: https://www.ncbi.nlm.nih.gov/pmc/ articles/PMC4340368/

28. Ferrer Lues M. Reflexiones sobre la concepción de la salud como responsabilidad individual. Construyendo bioética en salud pública. Bioética y Sociedad en Latinoamérica. Fundación Interamericana Ciencia y Vida. 2012; 1: 111-115.

29. Taylor SJ y Bogdan R. Introducción a los métodos cualitativos de investigación. Barcelona: Paidós; 1987. p. 11-15.

30. Pedraz Marcos A, Zarco Colón J, Ramasco Gutiérrez M y Palmar Santos AM. Investigación Cualitativa. Colección Cuidados de Salud Avanzados. Madrid: Elsevier; 2014. p. 12-20.

31. León OG y Montero I. Métodos de investigación en Psicología y Educación. Las tradiciones cuantitativa y cualitativa. Madrid: McGraw Hill; 2015. p. 430-580.

32. Husserl E. Meditaciones cartesianas. México: FCE; 1996. p. 48-63.

33. Husserl E. Investigaciones Lógicas, 2. Madrid: Alianza editorial; 2002. p. 28-54.

34. Schütz A. Fenomenología del mundo social. Buenos Aires: Paidós; 1972. p. 12-19.

35. Morse JM y Richards L. Readme first for a user's guide to qualitative methods. Thousand Oaks: Sage Publications; 2002. p. 49-55.

36. Field PA y Morse JM. Nursing Research. The application of Qualitative Approaches. London: Chapman \& Hall; 1994. p. 23-41.

37. Polit DF y Tanato Beck C. Nursing Research. Principles and methods Philadelphia: Lippincott Williams \& Wilkins; 1995. p. 9-14.

38. Kvale S. Las entrevistas en Investigación Cualitativa. Madrid: Morata 2011.

39. Miles MB y Huberman AM. An expanded sourrcebook. Qualitative data analysis. Thousand Oaks: Sage Publications; 1994. p. 29-44.

40. Alvarenga MS, Martins MC, Sato KS, Vargas SV, Philippi ST y Scagliusi FB. Orthorexia nervosa behavior in a sample of Brazilian dietitians assessed by the Portuguese version of ORTO-15. Eat Weight Disord [Internet].2012 [cited 2016 Jan 14]; 17(1):29-35. Available from: https:// www.ncbi.nlm.nih.gov/pubmed/22751269

41. Varga M, Thege BK, Dukay-Szabó S, Túry F y van Furth EF. When eating healthy is not healthy: orthorexia nervosa and its measurement with the ORTO-15 in Hungary. BMC Psychiatry [Internet]. 2014 [cited 2016 Jan 18]; 28(14):59. Available from: https://www.ncbi.nlm.nih.gov/ pmc/articles/PMC3943279/

42. Asil E y Sürücüoğlu MS. Orthorexia Nervosa in Turkish Dietitians. Eco Food Nutr [Internet]. 2015 [cited 2016 Mar 22]; 54(4): 303-313. Available from: https://www.ncbi.nlm.nih.gov/pubmed/25602930

43. Kummer A, Dias FM y Teixeira AL. On the concept of orthorexia nervosa Scand J Med Sci Sports [Internet]; 2008 [cited 2015 Dec 27]; 18(3): 395396. Available from: https://www.ncbi.nlm.nih.gov/pubmed/18435688

44. Dell'Osso L, Abelli M, Carpita B, Pini S, Castellini G, Carmassi C y Ricca V. Historical evolution of the concept of anorexia nervosa and relationships with orthorexia nervosa, autism, and obsessivecompulsive spectrum. Neuropsychiatric Disease and Treatment [Internet]. 2016 [cited 2016 Jul 11]; 12:1651-1660. Available from: http:// www.ncbi.nlm.nih.gov/pmc/articles/PMC4939998/pdf/ndt-12-1651.pdf

45. Alonso LE, Fernández Rodríguez CJ e lbáñez Rojo R. Crisis y nuevos patrones de consumo: discursos sociales acerca del consumo ecológico en el ámbito de las grandes ciudades españolas. Empiria: Revista de Metodología de Ciencias Sociales [Internet]. 2014 [cited 2016 Jul 25]; 29: 13-38. Available from: http://revistas.uned.es/index. php/empiria/article/view/12939/12116 